http://jmscr.igmpublication.org/home/

ISSN (e)-2347-176x ISSN (p) 2455-0450

crossref DOI: https://dx.doi.org/10.18535/jmscr/v7i7.59

\title{
A Study of Clinical Presentation and Risk Factors of Carcinoma Rectum
}

\author{
Authors \\ Dr Prashanth Thalluri MS ${ }^{1}$, Dr T Dheeraj ${ }^{2}$, Dr K Naveen; MS ${ }^{3}$, Dr V Tata Rao; MS $^{4}$ \\ ${ }^{1,2} 3$ rd Year Post Graduate, ${ }^{3}$ Asst. Professor, ${ }^{4}$ Professor \\ Department of General Surgery, NRI Academy of Sciences, Chinakakani
}

\section{Aims and Objectives}

1. To study age distribution of carcinoma rectum.

2. To study sex distribution of carcinoma rectum.

3. To study varied clinical presentation of carcinoma rectum.

4. To study the risks associated with various lifestyle factors.

\section{Etiology of Carcinoma Rectum}

The development of colorectal malignancy involves interplay between genetic and environmental influences. Colorectal cancers that develop in individuals without hereditary links are referred to as "sporadic," and account for $75 \%$ of all colorectal cancers. A potential genetic influence is identified in the remaining $25 \%$ of patients, including family history (15\% to $20 \%)$; Lynch syndrome $(5 \%)$; and FAP $(<1 \%)$.

The aetiology is multifactorial and includes risk factors such as: increasing age, male sex and previous colorectal cancer. Lifestyle factors may also contribute to a higher risk. Lack of physical activity, low fruit and vegetable intake, low fibre and a high fat diet, overweight and obesity, tobacco use and alcohol consumption have all been associated with a higher risk. ${ }^{1}$
Adenoma is the precursor to rectal carcinoma. Approximately $10 \%$ of adenomas progress to invasive carcinomas through a well-defined sequence of genetic change called the adenomacarcinoma sequence. This process may take 10 to15 years.

\section{Inflammatory Bowel Disease}

Patients with inflammatory bowel disease (IBD) are at significantly increased risk for developing colorectal cancer; the risk is proportional to the extent and duration of disease. In ulcerative colitis patients, where the risk of cancer appears to begin after 8 to 10 years of disease and increases at a rate of about $0.5 \%$ to $1.0 \%$ per year. Currently it is believed that the cancer risk is equivalent in Crohn and ulcerative colitis patients who have disease of similar duration and extent. An increased risk is also seen in patients with an onset of Crohn's disease before the age of 30 years.

\section{Hereditary Rectal Cancer}

About $20 \%$ of all rectal cancer cases might have a familial component. Most of the known familial syndromes are inherited in an autosomal-dominant pattern, resulting in a 50\% risk for a child of an affected individual to bear the predisposition for the cancer form. 


\section{Familial Adenomatous Polyposis}

It accounts for $1 \%$ of all colorectal cancers, is characterized by early onset of hundreds to thousands of polyps throughout the colon. The disease is inherited as an autosomal dominant trait; therefore, $50 \%$ of offspring from an affected individual will develop polyposis coli. Variants of FAP are Gardner syndrome and Turcot syndrome.

\section{Lynch Syndrome}

Lynch syndrome accounts for 5\% to $6 \%$ of colorectal cancers. Its phenotypic features include early-onset colorectal cancer (a mean age of 46 years), synchronous or metachronous colorectal cancers (noted in $35 \%$ of cases), and a predominance of right-sided tumors. Lynch I syndrome refers to the cohort with colorectal cancer only, while Lynch II syndrome refers to the cohort of patients with colorectal cancer and other associated adenocarcinomas of the ovary, pancreas, breast, bile duct, endometrium, stomach, genitourinary tract, and small bowel.. Lifetime risk is estimated at approximately half compared with the syndromes mentioned above ${ }^{2}$.

\section{Clinical Features of Rectal Cancer}

Often, the early symptoms are so insignificant that the patient does not seek advice for 6 months or more, and the diagnosis is often delayed in younger patients as these symptoms are attributed to benign cause.

\section{Bleeding Per Rectum}

Bleeding is the earliest and most common symptom. There is nothing characteristic about the time at which it occurs, nor is the colour or the amount of blood distinctive. the bleeding in every respect simulates that of internal haemorrhoids (haemorrhoids and carcinoma sometimes coexist).

\section{Altered Bowel Habits}

This is the next most frequent symptom. A patient who has to get up early in order to defaecate, or one who passes blood and mucus in addition to faeces ('early-morning bloody diarrhoea'), is usually found to be suffering from carcinoma of the rectum. Often, it is the patient with an annular carcinoma at the rectosigmoid junction who suffers with increasing constipation, and the one with a growth in the ampulla of the rectum who has early-morning diarrhoea.

\section{Tenesmus}

The patient may endeavour to empty the rectum several times a day (spurious diarrhoea), often with the passage of flatus and a little bloodstained mucus ('bloody slime').

\section{Pain}

If the growth of a tumour is constricting the rectum, abdominal colic may be the main complaint. Local anorectal pain is less common. When a deep carcinomatous ulcer of the rectum erodes the prostate or bladder, there may be severe pain. Pain in the back, or sciatica, occurs when the cancer invades the sacral plexus. Weight loss is suggestive of hepatic metastases. Invasion or compression of the pelvic blood vessels and lymphatics may produce unilateral or bilateral leg oedema

\section{Signs}

Tumours in the lower and middle thirds of the rectum can be felt by digital rectal examination and assessed; by asking the patient to strain, even some tumours in the upper third can be 'tipped' with the finger. After it is removed, the finger should be examined for tell-tale traces of mucus, pus or blood. Proctoscopy can be used to inspect the anus, anorectal junction and lower rectum (up to $10 \mathrm{~cm}$ ). Biopsy can be performed of any suspicious areas.

\section{Abdominal Examination}

Abdominal examination is normal in early cases. Occasionally, when an advanced annular tumour is situated at the rectosigmoid junction, signs of obstruction of the large intestine are present. By the time the patient seeks advice, metastases in the liver may be palpable. When the peritoneum has 
become studded with secondary deposits, ascites results.

\section{Stages Of Progression}

The rectum is defined as the bowel that is reached within $15 \mathrm{~cm}$ from the anus (anal verge) by a rigid rectoscope. The tumour is then inspected, and if it can be reached from the anus, it is assessed by digital palpation, which gives important information regarding possible fixation of the tumour. Diagnosis is made by multiple biopsies through a rectoscope or a flexible endoscope Modern tumour staging aims at evaluating the local and distant spread of the disease.

\section{Materials and Methods}

Study Design: The cross sectional study conducted in the department of surgery, NRI medical college and hospital, chinakakani.

Approval was taken from the ethical of institution.

Sample size: Total number of cases is 60 .

Duration of study: July 2016 to Nov 2018

Selection of cases: Patients provisionally diagnosed as having carcinoma rectum either clinically or radiologically are included in the study.

Written consents were taken from all the cases included in the study.

The presenting symptoms, detailed past history,family history and personal history of all the patients were recorded.

A detailed general and systemic examination was done.

Routine investigations like complete blood count,viralmarkers, bloodurea,serumcreatinine,ran dom blood sugar,blood grouping and typing,ultra sound abdomen, chest $\mathrm{x}$ ray,colonoscopy.

\section{Inclusion Criteria}

1. All patients with provisional diagnosis as carcinoma rectum attending NRI medical college and Hospital, Chinakakani.

2. Patients above $18 \mathrm{yrs}$

\section{Exclusion Criteria}

1) Patients below 18 yrs were excluded from the study.
2) Patients with bleeding per rectum due to benign polyps, benign ulcers, inflammatory bowel disease, diverticulosis.

\section{Statistical methods employed}

Description of the categorial variables related to demographical, clinical, radiological and operative findings were presented as frequencies or percentages. Data was also pictorially presented either by pie charts or bar charts. Arthematic means are reported for age of males and females included in the study.

\section{Results}

A total of 60 patients were recruited in the study. The mean age of the patients was 49 years within the range of 20-72 years. Table 1 reports the age distribution of patients included in the study and the figure 1 shows the distribution of patients in terms of their age.

Table 1: Age distribution of the patients

\begin{tabular}{|l|c|c|}
\hline Age group (years) & Total & Total Percentage \\
\hline $18-30$ & 3 & 5.0 \\
\hline $31-40$ & 16 & 26.7 \\
\hline $41-50$ & 20 & 33.3 \\
\hline $51-60$ & 10 & 16.7 \\
\hline $61-70$ & 9 & 15.0 \\
\hline 71 and over & 2 & 3.3 \\
\hline
\end{tabular}

Figure 1: Age distribution of the patients.

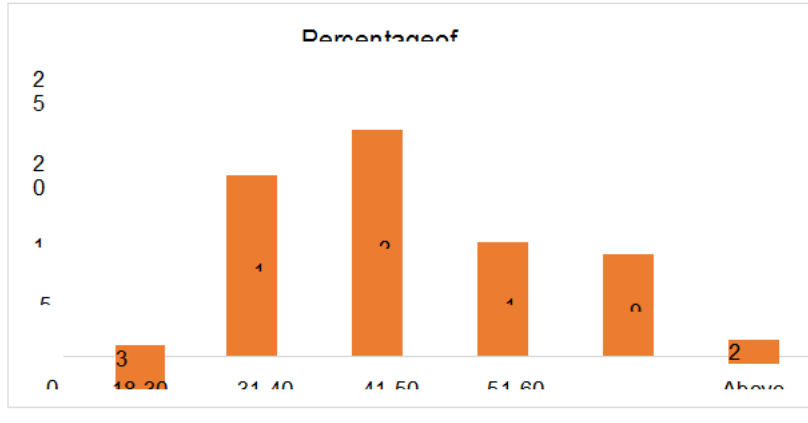

Interms of the gender distribution of the patients, $42(70 \%)$ were males and $18(30 \%)$ were females in our study carcinoma rectum was more common in males. Table 2 and figure 2 presents these results.

Table 2: Sex distribution of patients with Rectal Carcinoma

\begin{tabular}{|l|c|c|}
\hline Sex & Total & Total Percentage \\
\hline Males & 42 & 70.0 \\
\hline Females & 18 & 30 \\
\hline
\end{tabular}


Figure 2: Sex distribution of patients with Carcinoma Rectum $(\mathrm{N}=60)$

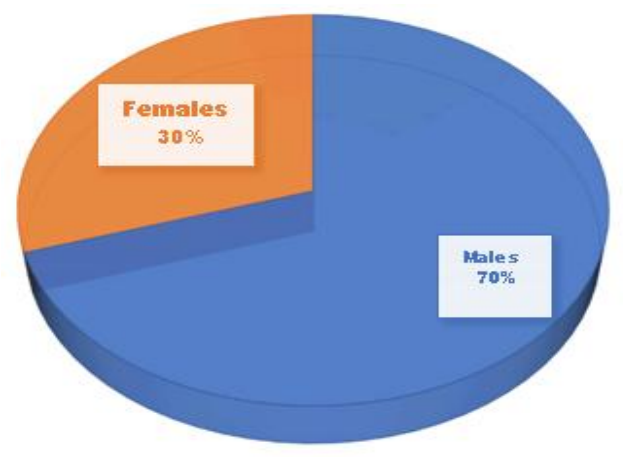

\section{Clinical Presentation}

Table 3 shows among 60 carcinoma rectum cases $38(63.3 \%)$ presented with bleeding in rectum, 20 $(33.3 \%)$ presented with altered bowel habits, 12 (20\%) presented with abdominal pain, 8 (13.3\%) presented with Obstruction, $6(10 \%)$ presented with Loss of appetite, and 6(10\%) presented with Weightloss. In our study rectal bleeding was the most common complaint with which carcinoma rectum patients werepresented.

Table 3: Clinical symptoms presentation of carcinoma rectum $(\mathrm{n}=60)$

\begin{tabular}{|l|c|c|}
\hline Symptoms & Total & $\begin{array}{c}\text { Percentage of patients } \\
\text { reported with the symptom }\end{array}$ \\
\hline Rectal bleeding & 38 & 63.3 \\
\hline Altered bowel habit & 20 & 33.3 \\
\hline Abdominal pain & 12 & 20.0 \\
\hline Obstruction & 8 & 13.3 \\
\hline Loss of appetite & 6 & 10.0 \\
\hline Weight loss & 6 & 10.0 \\
\hline
\end{tabular}

Figure 3: Clinical symptoms presentation of carcinoma rectum $(n=60)$

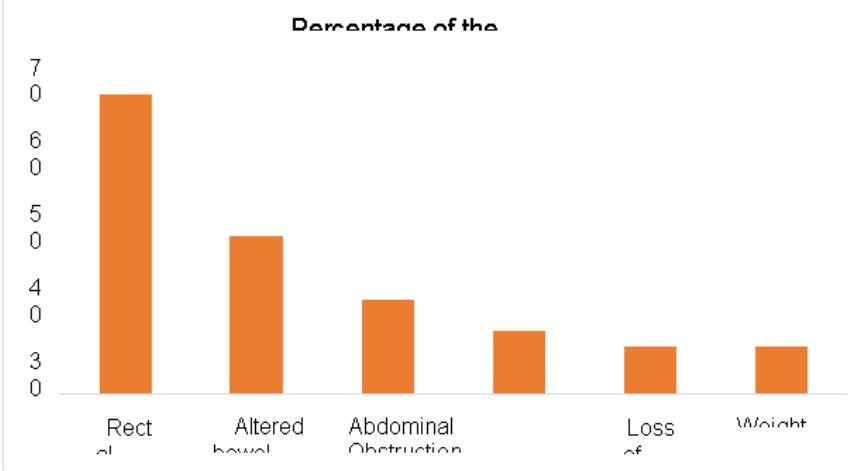

Asstated in the table 4, our study shows that patients included in this study $49(81.7 \%)$ patients were on mixed dietary habits, $11(18.3 \%)$ were on vegetarian diet, $50(83.3 \%)$ patients were smokers,
$46(76.7 \%)$ were alcohol regularly consuming alcohol. Of all the patients $34(56.7 \%)$ of the patients were obese with $\mathrm{BMI}>30$.

Table 4: Dietary habits and patients with $\mathrm{BMI}>30$ $(\mathrm{n}=60)$

\begin{tabular}{|l|c|c|}
\hline Category & Total & $\begin{array}{c}\text { Percentage of patients } \\
\text { reported in the category }\end{array}$ \\
\hline Mixed diet & 49 & 81.7 \\
\hline Vegetarian diet & 11 & 18.3 \\
\hline Smoking & 50 & 83.3 \\
\hline Alcohol & 46 & 76.7 \\
\hline BMI>30 & 34 & 56.7 \\
\hline
\end{tabular}

Figure 4: Dietary habits and patients with BMI $>30(n=60)$

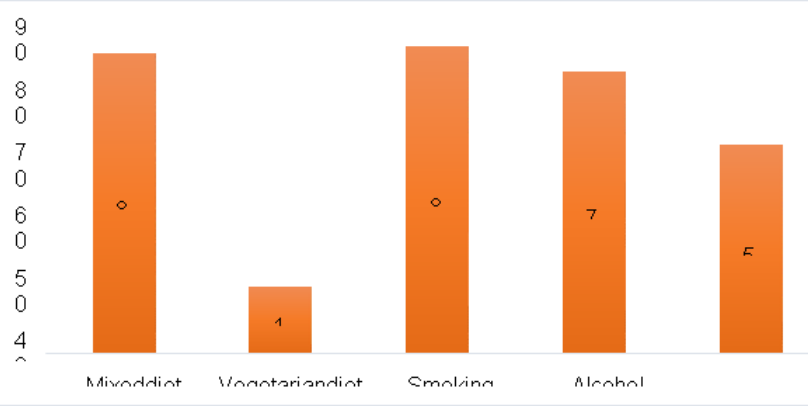

Table 5 presents the findings from clinical examination of the carcinoma of rectum showed, pallor was seen in $36(60 \%)$, edema in $10(16.7$ $\%)$, abdomen tenderness in 7 (11.7\%), hepatomegaly in $2(3.3 \%)$, palpable per rectal growth in $48(80 \%)$ and ascites in $2(3.3 \%)$. In our study palpable rectal growth was present in majority of the patients $(80 \%)$.

Table 5: Findings from examination of carcinoma of rectum in patients $(n=60)$.

\begin{tabular}{|l|c|c|}
\hline Examination & Total & $\begin{array}{c}\text { Percentage of } \\
\text { patients }\end{array}$ \\
\hline Pallor & 36 & 60.0 \\
\hline Lymphadenopathy & 0 & 0.0 \\
\hline Edema & 10 & 16.7 \\
\hline Abdomen tenderness & 7 & 11.7 \\
\hline Hepatomegaly & 2 & 3.3 \\
\hline Palpable per rectal growth & 48 & 80.0 \\
\hline Ascites & 2 & 3.3 \\
\hline
\end{tabular}


Figure 5: Findings from examination of carcinoma of rectum in patients $(n=60)$.

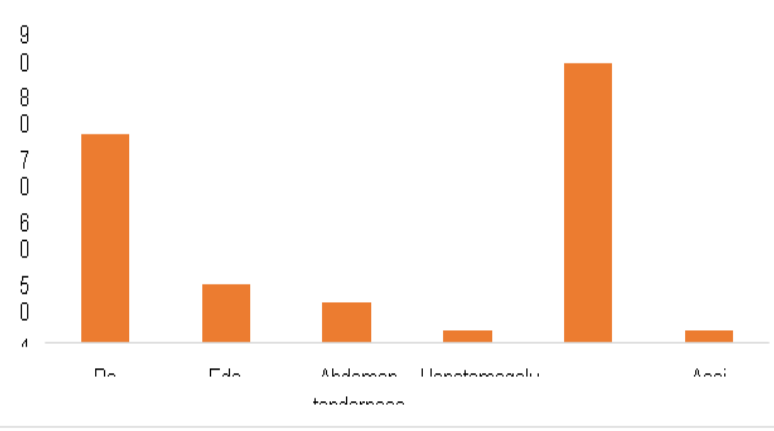

Results from histological examination of the rectal tissue are presented in table 6. It was observed that $14 \quad(23.3) \%$ patients showed well differentiated adenocarcinoma, 29 (48.3\%) patients showed moderately differentiated adenocarcinoma, $8(16.7 \%)$ patients showed poorly differentiated adenocarcinoma and $6(11.7 \%)$ patients showed signetring cell carcinoma.
Table 6: Findings from histological examination of rectal tissue in patients with carcinoma of rectum $(n=60)$.

\begin{tabular}{|l|c|c|}
\hline Histological finding & Total & $\begin{array}{c}\text { Percentage of } \\
\text { patients }\end{array}$ \\
\hline $\begin{array}{l}\text { Well differentiated } \\
\text { Adenocarcinoma }\end{array}$ & 14 & 23.3 \\
\hline $\begin{array}{l}\text { Moderately differentiated } \\
\text { adenocarcinoma }\end{array}$ & 29 & 48.3 \\
\hline $\begin{array}{l}\text { Poorly differentiated } \\
\text { adenocarcinoma }\end{array}$ & 10 & 16.7 \\
\hline Signet ring cell carcinoma & 7 & 11.7 \\
\hline
\end{tabular}

Figure 6: Findings from histological examination of rectal tissue in patients with carcinoma of rectum $(n=60)$.

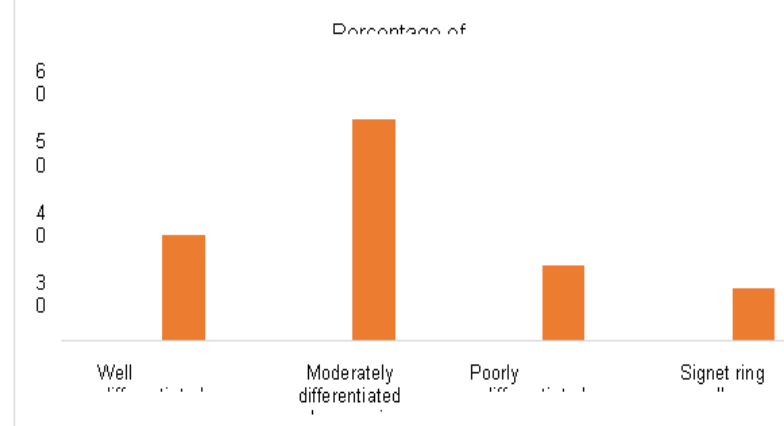

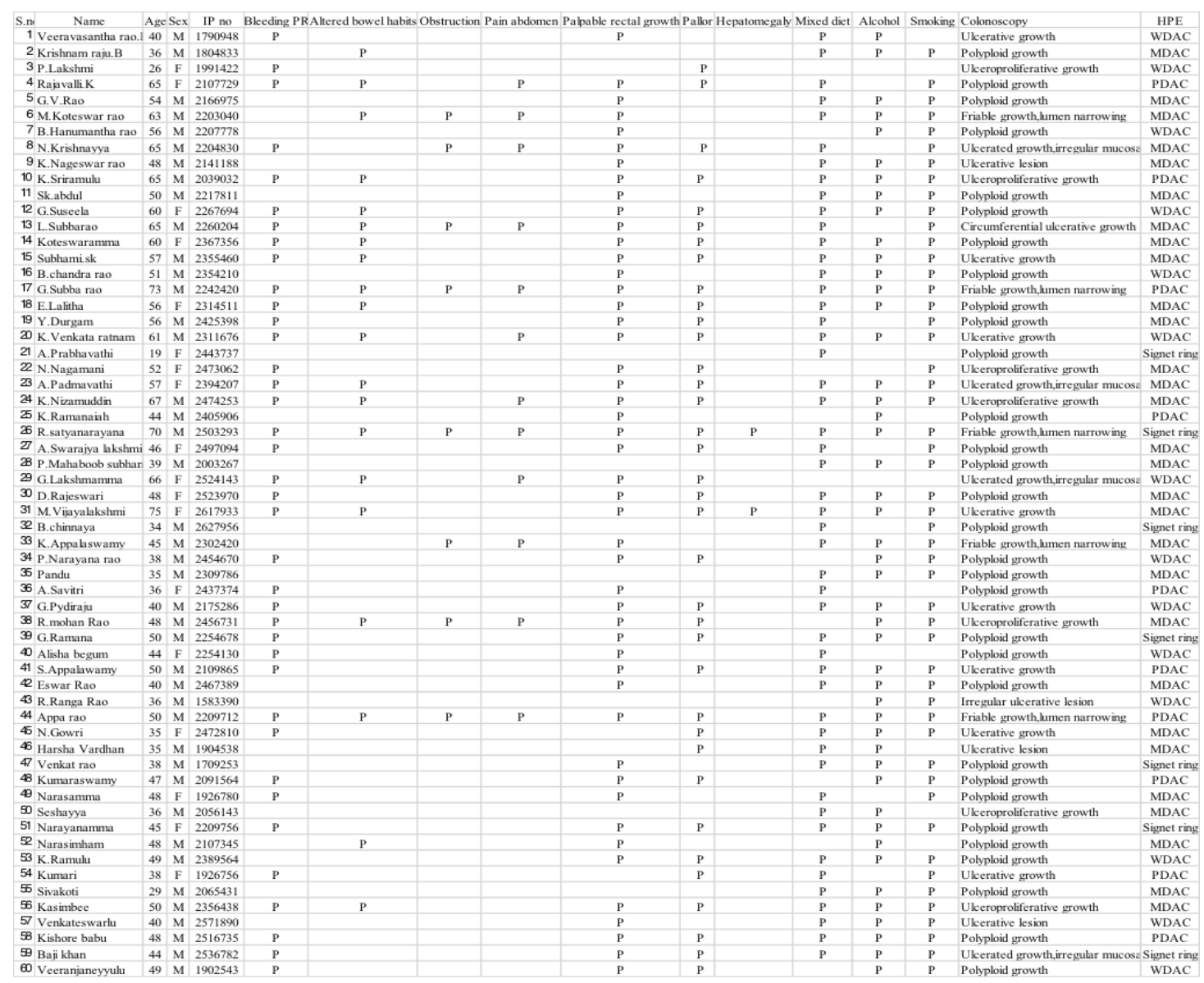




\section{JMSCR VoI||07||Issue||07||Page 311-319||July}

\section{Discussion}

Age distribution of patients according to our study-3(5\%) were in age group 18-30,16(26.7\%) were in age group 31-40, 20(33.3\%) were in age group 41-50 and $10(16.7 \%)$ in age group 51$60,9(15 \%)$ in age group $61-70,2(3.3 \%)$ in age group above 71 . Most of the patients were in age group 31-50 constitueting a total of $60 \%$.Mean age of present study was 49 .

Similar results were obtained by Rasool.et.al in his study of incidence of colorectal cancer in association with risk factors in a teritiary care hospital in Srinagar,Kashmir with a mean age of 48.

Table: Comparision of Age Distribution of Carcinoma Rectum

\begin{tabular}{|l|c|c|}
\hline AUTHOR & $\begin{array}{c}\text { YEAR OF } \\
\text { STUDY }\end{array}$ & $\begin{array}{c}\text { MEAN AGE } \\
\text { IN YEARS }\end{array}$ \\
\hline Deo S V.et.al & 2001 & 45.3 \\
\hline Eltinay and Guraya & 2006 & 42.7 \\
\hline $\begin{array}{l}\text { Abdulrahman } \\
\text { M.Aljebreen }\end{array}$ & 2007 & 55 \\
\hline Rasool.et.al & 2008 & 48 \\
\hline SudarshanV.et.al & 2013 & 43 \\
\hline Present study & $2016-18$ & 49 \\
\hline
\end{tabular}

According to our sex distribution of carcinoma rectum was $70 \%$ in males and 305 in females; there is slightly higher male ratio compared to results obtaines by Sudarshan V et.al, Rasool A, et.al and according to Ferlay $\mathbf{J}$, this disease is slightly more common in men than in women ,by seven to five.

Table: Comparision of Sex Distribution of Carcinoma Rectum

\begin{tabular}{|l|c|c|c|}
\hline AUTHOR & $\begin{array}{c}\text { YEAR OF } \\
\text { STUDY }\end{array}$ & $\begin{array}{c}\text { MALES } \\
(\mathbf{\%})\end{array}$ & $\begin{array}{c}\text { FEMALES } \\
(\boldsymbol{\%})\end{array}$ \\
\hline $\begin{array}{l}\text { Eltinay and } \\
\text { Guraya }\end{array}$ & 2006 & $33(76.7)$ & $10(23.2)$ \\
\hline $\begin{array}{l}\text { Abdulrahman } \\
\text { M.Aljebreen }\end{array}$ & 2007 & $65(58)$ & $48(420$ \\
\hline RasoolA,et.al & 2008 & $56(57.7)$ & $41(42.2)$ \\
\hline Sudarshan V et.al & 2013 & $134(57.51)$ & $99(42.48)$ \\
\hline Present study & $2016-18$ & $42(70)$ & $18(30)$ \\
\hline
\end{tabular}

varied clinical presentation of carcinoma rectum according to our study was $-63.3 \%$ presented with bleeding per rectum, $33.3 \%$ presented with altered bowel habits ,20\% presented with pain abdomen, $13.3 \%$ presented with obstruction and
$10 \%$ presented with loss of weight. In our study rectal bleeding was the most common presentation.compared to other studies incidence of bleeding per rectum is higher in our study.

Table: Comparision of Clinical Presentation of Carcinoma Rectum

\begin{tabular}{|l|c|c|}
\hline AUTHOR & $\begin{array}{c}\text { YEAR OF } \\
\text { STUDY }\end{array}$ & $\begin{array}{c}\text { CLINICAL } \\
\text { PRESENTATION n(\%) }\end{array}$ \\
\hline $\begin{array}{l}\text { Eltinay and } \\
\text { Guraya }\end{array}$ & 2006 & Bleeding per rectum 16(37.1) \\
\hline $\begin{array}{l}\text { Abdulrahman } \\
\text { M.Aljebreen }\end{array}$ & 2007 & Bleeding per rectum 70(62) \\
\hline Present study & $2016-18$ & Bleeding per rectum 38(63.3) \\
\hline
\end{tabular}

Our study showed personal habits in 60 carcinoma cases as follows: mixed diet in 49(81.7\%), vegetarian diet in 11(18.35), smoking in $15(83.3 \%)$, alcohol in $46(76.7 \%)$ and $\mathrm{BMI}>30$ in $34(56,7 \%)$.

\section{Risks Associated with Colorectal Carcinoma}

\begin{tabular}{|l|c|}
\hline DECREASED RISK & INCREASED RISK \\
\hline Physical activity & Red meat \\
\hline Food containing fibre diet & Processed meat \\
\hline & Alcohol drinks(men) \\
\hline & Body fatness \\
\hline & Abdominal fatness \\
\hline & Adult attained height \\
\hline
\end{tabular}

There are several potential underlying mechanisms for a positive association of red meat consumption with colorectal cancer.red meat contains haem, which promotes the formation of potentially carcinogenic $\mathrm{N}$-nitroso compounds as well as cytotoxic alkenals forms from fat peroxidation.red meat cooked at high temperatures ,results in the production of heterocyclic amines and polycyclic aromatic hydrocarbons that can cause rectal cancer with a genetic predisposition. CUP meta - analyses for sources of fibre and colorectal cancer showed a $10 \%$ decreased risk for cereal fibre.

On general and systemic examination our study showed Pallor was seen in 36(60\%), edema in $10(16.7 \%)$, abdominal tenderness in $7(11.7 \%)$, hepatomegaly in $2(3.3 \%)$, palpable per rectal growth in $48(80 \%)$, and ascites in $2(3.3 \%)$.

According to Eltinay and Guraya study of colorectal carcinoma: clinicopathological pattern 
and outcome of surgical management varied clinical findings are anemia 20(46.4\%), abdominal distension 11(25.5\%), hepatomegaly 4(9.2\%).

Upto $80 \%$ of rectal cancers are palpable.the site of rectal cancers are measured in centimetres from the anal verge. The area upto $8 \mathrm{cms}$ above the dentate line can be assessed for size, ulceration, lymph nodes and possible fixation.

According to our study histological picture 60 carcinoma rectum cases were 14(23.3\%) well differientiated adenocarcinoma, 29(48.3\%) moderately differentiated adenocarcinoma, $10(16.7 \%)$ poorly differentiated adenocarcinoma and $7(11.7 \%)$ signet ring cell carcinoma. Moderately differentiated adenocarcinoma was most common according to our study. Literature supporting are -

Table: Comparision of Histology of Carcinoma Rectum

\begin{tabular}{|l|c|c|}
\hline AUTHOR & $\begin{array}{c}\text { YEAR OF } \\
\text { STUDY }\end{array}$ & $\begin{array}{c}\text { MODERATELY } \\
\text { DIFFERENTIATED } \\
\text { ADENOCARCINOMA n (\%) }\end{array}$ \\
\hline $\begin{array}{l}\text { Eltinay and } \\
\text { Guraya }\end{array}$ & 2006 & $17(40 \%)$ \\
\hline $\begin{array}{l}\text { Abdulrahman } \\
\text { M.Aljebreen }\end{array}$ & 2007 & $63(56 \%)$ \\
\hline Present study & $2016-18$ & $29(48.3 \%)$ \\
\hline
\end{tabular}

\section{Conclusion}

The present study includes 60 cases of carcinoma rectum. The was undertaken with a name of $\mathrm{A}$ STUDY OF CLINICAL PRESENTATION AND RISK FACTORS OF CARCINOMA RECTUM. Study was done on patients with provisional diagnosis of carcinoma rectum attending to the department of general surgery, NRI medical college and hospital, chinnakakani during the period between July

Objectives being study of mean age and sex prevalence, identification of various modes of presentation and associated risk factors. Informed and written consent was taken from the individuals included in the study.

1) In our present study $3(5 \%)$ were in age group $18-30,16(26.7 \%)$ were in age group 31-40, $20(33.3 \%)$ were in age group 41-50 and $10(16.7 \%)$ in age group $51-60,9(15 \%)$ in age group 61-70, 2(3.3\%)in age group above 71. Most of the patients were in age group 3150 constitueting a total of $60 \%$.Mean age of present study was 49 years.

2) There were $42(70 \%)$ males and $18(30 \%)$ females in the present study.In our study carcinoma rectum was more in males.

3) In our present study among 60 carcinoma rectum cases $38(63.3 \%)$ presented with bleeding in rectum, $20(33.3 \%)$ presented with altered bowel habits, $12(20 \%)$ presented with abdominal pain, 8 (13.3\%) presented with Obstruction, $6(10 \%)$ presented with Loss of appetite, and 6(10\%) presented with Weight loss. Inourstudyrectal bleeding was the most common complaint with which carcinoma rectum patients werepresented.

4) Examination findings in our present study was pallor was seen in $36(60 \%)$, edema in 10 (16.7\%), abdomen tenderness in 7 (11.7\%), hepatomegaly in $2(3.3 \%)$, palpable per rectal growth in 48 (80\%) and ascites in $2(3.3 \%)$. In our study palpable rectal growth was present in majority of the patients $(80 \%)$.

5) Personal history of our study was $49(81.7 \%)$ patients were on mixed dietary habits, 11 (18.3\%) were on vegetarian diet, $50(83.3 \%)$ patients were smokers, $46(76.7 \%)$ were alcohol regularly consuming alcohol. Of all the patients $34(56.7 \%)$ of the patients were obese withBMI $>30$.

6) Histological picture of 60 carcinoma patients of our study was 14 (23.3)\% patients showed well differentiated adenocarcinoma, 29 $(48.3 \%)$ patients showed moderately differentiated adenocarcinoma, 8 (16.7\%) patients showed poorly differentiated adeno carcinoma and 6(11.7\%) patients showed signetring cell carcinoma. In our study moderately differentiated adenocarcinoma is the most frequent histology.

A Study with more number of cases is required for better understanding and management of the disease. 


\section{References}

1. Parkin DM. International variation. Oncogene 2004;23:6329-40

2. Parkin DM, Pisani P, Ferlay J. Global cancer statistics.CA Cancer J Clin 1999;49:33-64.

3. Centre for diseasecolorectal cancer risk factors 2009.

4. Heriot AG, Hicks RJ, Drummond EG, etal. Does positron emission tomography change management in primary rectal cancer? A prospective assessment. Diseases of the colon and rectum.Apr 2004;47(4):451-458.

5. Vogelstein B, fearon ER, HanniltonSR, genetic alterations during colorectal tumor no development Nengl J Medsep 1 1998,31(9) 525-532

6. Surgery OCSSFC national guidelines for colorectal cancer 2008.

7. Cunningham D, Atkin wlenz $\mathrm{HJ}$ et al colorectal cancer Lancetmarzo 2010:375 (97 19): 1030-1047.

8. Japersonkw, Tuohy Tm, nekalson DW, brut RW, hereditary and familial colon cancer, gastroentroloxlgy june 610:130(6):2044-2058.

9. Jemal A, Brag F centre $\mathrm{mm}$ et al global cancer statistics, CA cancer selin ,2011,61:69.

10. Mohandas km, desi DC, epidemiology of digestive cancers in indiaV.large and small bowel .indian $\mathrm{j}$ gastro enterol 1999jul sep 18(3):118-121.

11. Keighley MRB, Williams NS. Surgery of the anus, rectum and colon.Second edition ed. London: W.B.Saunders; 1993.

12. Sobin LH, Gospodarowicz MK, Wittekind C, International Union against Cancer. TNM classification of malignanattumours. $7^{\text {th }}$ ed. Chichester, West Sussex, UK; Hoboken, NJ: Wiley-Blackwell; 2010.

13. Hermanek P, Wittekind C. Residual tumor (R) classification and prognosis. Semin Surg Oncol 1994;10:12-20.
14. MERCURY. Diagnostic accuracy of preoperative magnetic resonance imaging in predicting curative resection of rectal cancer: prospective observational study. BMJ.Oct14 2006;333(7572):779

15. Burton S, Brown G, Daniels I, etal.MRI identified prognostic features of tumours in distal sigmoid,rectosigmoid,and upper rectum:treatment with radiography and chemotherapy.Int J Radiat Oncol Biol Phys. Jun 1 2006;65(2):445-451

16. Mac Dermid E, Hooton G, MacDonald M, etal. Improving patient survival with the colorectal cancer multi-disciplinary team. Colorectal Dis.Mar 2009;11(3):291-295.

17. Deo SV, Shukla NK, Srinivas G, Mohanti BK, Raina V, Sharma A, Rath GK. Colorectal cancers-experience at a regional cancer centre in India.Trop Gastroenterol. 2001Apr-Jun;22(2):83-86.

18. Eltinay OF， Guraya SY. Colorectal carcinoma: Clinico pathological pattern and outcome on surgical management. Saudi J Gastroenterol 2006;12:83-86.

19. Aljebreen AM. Clinico pathological patterns of colorectal cancer in Saudi Arabia: Younger with an advanced stage presentation.Saudi J Gastroenterol 2007;13:84-87.

20. Rasool S, Bari S, Rashid A, Wani R,Wani G. Peer:Outcome of patients with acute intestinal obstruction due to coloretalcarcinoma. Int J Surg 2009; 20: DOI: $10.5580 / \mathrm{C} 35$.

21. Sudarshan V, Hussain N,Gahine R, Mourya J.Colorectal cancer in young adults in a teritiary care hospital in Chhattisgarh, Raipur. Indian J Cancer 2013;50:337-340.

22. Ferlay J, Shin HR, Bray F, etal GLOBOCAN 2008, Cancer Incidence and Mortality Worldwide: IARC Cancer Base No.10.Lyon, France: International Agency for Research on Cancer;2010.

23. Parkin D, Wheelan SI,Ferlay J,etal. Cancer 
Incidence in Five Continents;Vol.1 to 7.Lyon:IARC 2005.

24. Centres for disease control and prevention. http://www.cdc.gov/cancer/colorectal/stati stics/race.htm.2011.

25. Goldacre MJ, Wotton CJ, Yeates D,et al. Cancer in patients with ulcerativecolitis, Crohn's disease and coeliac disease:record linkage study. Eur J GastroenterolHepatol 2 008:20:297-304.

26. Lynch H,de la ChapelleA.Hereditary Colorectal cancer. NEngl J Med 2003;348:919-932.

27. Weitz J, Koch M, Debus J,etal. Colorectal cancer. Lancet 2005;365:153-165.

28. McSherry C, Cornell G, Glenn F. Carcinoma of the colon and rectum.Ann Surg, 1969. 169:p502-509.

29. Bretagnol F, Rullier E,George B,et al. Local therapy for colorectal cancer. Still Contraversial?__ Dis Colon Rectum, 2007.50:p523-533.

30. Minardi AJ Jr., Sittig KM, Zibari GB, McDonald JC. Colorectalcancr in the young patient.AmSurg 1998;64:849-853. 